\title{
Individual Characteristic and Cadmium Level in Blood on Tradisional Metal Foundry Workers \\ by Yuliani Setyaningsih
}

Submission date: 16-Jul-2019 02:36PM (UTC+0700)

Submission ID: 1152305767

File name: C3.pdf (330.62K)

Word count: 3193

Character count: 16369 


\title{
Individual Characteristic and Cadmium Level in Blood on Tradisional Metal Foundry Workers
}

\author{
Yuliani Setyaningsih ${ }^{1}$, Ari Suwondo ${ }^{1}$, Ahmad Saihu ${ }^{2}$ \\ 'Occupational Health and Safety Department, ${ }^{2}$ Magister of Health Promotion, Public Health Faculty, \\ Diponegoro University, Semarang, Indonesia
}

\begin{abstract}
Cadmium is one type of seriously hazardous heavy metal if inhaled. Acute cadmium poisoning may result from exposure of cadmium oxide vapor during metal melting process. This study aims to determine the factors ofindividuals characteristic associated with levels of cadmium in the blood of workers. This research is an analytic observation research with cross sectional approach. Samples were taken purposively from 30 metal casting workers. The research variables are smoking habit, BMI, working hours, duration of work and occupation as independent variables and cadmium levels in the blood as dependent variables. Blood cadmium levels were measured using Atomic Absorbtion Spectophotometer (AAS). Data were analyzed using chi-square. Although there was no correlation between smoking habit and working hours on cadmium blood level ( $\mathrm{p}$ value $>0,05$ ) but there was correlation between nutritional status, duration of work and occupation to cadmium in blood (P value $<0.05$ ). There is a relationship between BMI, duration of work and type of work with cadmium levels in the blood of metal casting workers, for modification of workplace ventilation and the use of personal protective equipment to increase fume of cadmium in workplace.
\end{abstract}

Keywords: cadmium in blood, metal casting, individual characteristics

\section{INTRODUCTION}

Metal foundry industry is one of the industries producing pollutants that can pollute the environment. Sources of emissions of pollutants that exist among them are particles in the form of dust derived from metals such as lead, nickel, cadmium and beryllium ${ }^{1}$.

In the process of casting melting of raw materials is done at $\pm 13000 \mathrm{C}$. At this stage smoke and vapors produced are contained of metal particles (fume) consisting of unused metal powder finishing, steel, silicon, slag and carbon. This is exacerbated by the lack of adequat ventilation to cause workers inhaling the combustion gas continuously ${ }^{2}$

\section{Corresponding Author:}

Yuliani Setyaningsih

Occupational Health and Safety Department, Public Health Faculty, Diponegoro University, Jl. Prof. Sudarto, SH,Tembalang, Semarang, 50275 Email: yulianifkm@live.undip.ac.id
In addition to products result, the process of casting metals also produces heavy metals such as $\mathrm{Cd}, \mathrm{Cr}, \mathrm{Ni}$ and $\mathrm{Pb}$. This is a risk factor that is harmful to the health of workers because the side effects of heavy metals produced have high toxicity properties ${ }^{3}$. One of the dangers to be considered in connection with the metal foundry industry is the presence of cadmium. Cadmium is one of the heavy metals from the metal melting process, acute cadmium poisoning usually occurs due to cadmium oxide vapor from cutting of cadmium metal or a cadmium-containing metal mixture ${ }^{4}$.

This study aims to analyze relationship between the characteristics of individuals (Smoking Habit and Body Mass Index) and Occupational Factors (Type of Work, Duration of work and working hours) on levels of Cadmium in the blood of metal foundry workers.

\section{METHOD}

This is Explanatory Research, with cross sectional approach. The sample is the total population of 30 metal foundry workers. Blood sampling assisted by Health Center officer of sub-district Ceper, Klaten, Central 
Java. Primary data used in this research is obtained by questionnaire to know variable of individual factor and worker factor. In addition, the primary data were also obtained from the results of laboratory tests for cadmium levels in the blood. This examination was conducted at the Center for Environmental Health Engineering and Disease Control (BBTKLPP) Yogyakarta.

Data analysis used to know the relation of significance between individual factor and worker factor with cadmium level in blood, used Chi Square test.

\section{RESULTS AND DISCUSSIONS}

Description of the Research Variable: Based on the results of research obtained by the distribution of respondents based on smoking habits, most respondents have smoking habit as many as 16 respondents (53.3\%). While not smoking as many as 14 respondents (46.7\%). Data of respondent distribution based on nutritional status, most of respondent have normal status that is 20 respondents $(56,7 \%)$, while abnormal nutrition status is 10 respondent $(33,3 \%)$.

Respondents have a working duration for $>5$ years as many as 16 respondents (60\%). While the duration of work for $<5$ years as many as 14 respondents (40\%) and respondents who have working hours $<8$ hours / day as many as 21 respondents (70\%). While working hours $>8$ hours / day as many as 9 respondents (30\%), as well as respondents working on the foundry that is as many as 18 respondents (70\%). While in the finising of 12 respondents $(30 \%)$, respondents who are not exposed to cadmium are 21 respondents $(70 \%)$, while cadmium exposure is 9 respondents $(30 \%)$

Table 1: Distribution of Respondent's Characteristc

\begin{tabular}{|c|c|c|c|}
\hline No. & Variable & $\mathrm{n}=\mathbf{3 0}$ & $\%$ \\
\hline \multirow[t]{3}{*}{1.} & \multicolumn{3}{|l|}{ Smoking Habit } \\
\hline & a. Smoking & 16 & 53,3 \\
\hline & b. Non Smoking & 14 & 46,7 \\
\hline \multirow[t]{3}{*}{2.} & \multicolumn{3}{|l|}{ BMI } \\
\hline & a. Normal & 20 & 56,7 \\
\hline & b. Not normal & 10 & 33,3 \\
\hline \multirow[t]{3}{*}{3.} & \multicolumn{3}{|l|}{ Working Period } \\
\hline & a. $>5$ years & 16 & 53,3 \\
\hline & b. $\leq 5$ years & 14 & 46,7 \\
\hline
\end{tabular}

Conted...

\begin{tabular}{|c|c|c|c|}
\hline \multirow[t]{3}{*}{4.} & \multicolumn{3}{|l|}{ Working Hours } \\
\hline & a. $<8$ hour/day & 21 & 70 \\
\hline & b. $\leq 8$ hour/day & 9 & 30 \\
\hline \multirow[t]{3}{*}{5.} & \multicolumn{3}{|l|}{ Type of Work } \\
\hline & a. Foundry & 18 & 60 \\
\hline & b. Finishing & 12 & 40 \\
\hline \multirow[t]{3}{*}{6.} & \multicolumn{3}{|l|}{ Cadmium in Blood } \\
\hline & a. Exposed & 9 & 30 \\
\hline & b. Not Exposed & 21 & 70 \\
\hline
\end{tabular}

Metal foundry workers are potentially exposed to Cadmium. In the process of casting the metal, in addition to producing metal products, it also produces heavy metals such as $\mathrm{Cd}, \mathrm{Cr}, \mathrm{Ni}$ and $\mathrm{Pb}$, This is a quite harmful risk to the health of traditional metal foundry workers, considering that the heavy metals have the side effects with high level of toxicity.

It is also worsened by the lack of adequate ventilation, thus it makes the workers to inhale gas from burning result continuously. In doing the job, there is no worker who uses personal protective equipment, even having their meals and drinking is also done in the workplace. Therefore, preventive steps should be prepared much earlier to overcome the possible harmful impact to the workers.

Cadmium can cause interference and even able to cause damage to the kidney system. Such damage may occur in the tubules of the kidneys. The symptom of the damage that can occur in the kidney because of the cadmium is the occurrence of amniouria, glucosuria and the calcium and phosphorus urinary abnormalities ${ }^{5}$

Smoking is one of the main sources of cadmium exposure. Therefore we consider the possibility of smoking as confounding variables in exposure to cadmium in non smokers. The exact mechanism is not yet known whether the smoking causes kidney damage. The mechanism that can be explained is that smoking will make the kidneys more sensitive to cadmium toxicity $^{6}$ 
Table 2: Bivariate Analysis between Smoking Habit, BMI, Type of Work, Working Period, Length of Work, Working Hour and Cadmium Level in Blood

\begin{tabular}{|c|c|c|c|c|c|c|c|}
\hline \multirow{2}{*}{ No. } & \multirow{2}{*}{ Variable } & \multicolumn{2}{|c|}{ Cadmium } & \multirow{2}{*}{$\mathbf{P}$} & \multirow{2}{*}{$\mathbf{R P}$} & \multicolumn{2}{|c|}{$95 \% \mathrm{CI}$} \\
\hline & & Exposed & Not Exposed & & & Lower & Upper \\
\hline \multirow[t]{3}{*}{1.} & \multicolumn{7}{|l|}{ Smoking Habit } \\
\hline & Smoking & $6(37,5 \%)$ & $10(62,5 \%)$ & \multirow{2}{*}{0,440} & \multirow{2}{*}{1,750} & \multirow{2}{*}{0,535} & \multirow{2}{*}{5,729} \\
\hline & Non Smoking & $3(21,4 \%)$ & $11(78,6 \%)$ & & & & \\
\hline \multirow[t]{3}{*}{2.} & \multicolumn{7}{|l|}{ Body Mass Index } \\
\hline & Normal & $0(0 \%)$ & $10(100 \%)$ & \multirow{2}{*}{0,013} & \multirow{2}{*}{1,818} & \multirow{2}{*}{1,223} & \multirow{2}{*}{2,703} \\
\hline & Not Normal & $9(35 \%)$ & $11(65 \%)$ & & & & \\
\hline \multirow[t]{3}{*}{3.} & \multicolumn{7}{|l|}{ Type of Work } \\
\hline & Foundry & $8(44,4 \%)$ & $10(55,6 \%)$ & \multirow{2}{*}{0,049} & \multirow{2}{*}{5,333} & \multirow{2}{*}{0,762} & \multirow{2}{*}{37,348} \\
\hline & Finishing & $1(8,3 \%)$ & $11(91,7 \%)$ & & & & \\
\hline \multirow[t]{3}{*}{4.} & \multicolumn{7}{|l|}{ Working Period } \\
\hline & $>5$ Years & $9(56,3 \%)$ & $7(43,8 \%)$ & \multirow{2}{*}{0,001} & \multirow{2}{*}{0,438} & \multirow{2}{*}{0,251} & \multirow{2}{*}{0,763} \\
\hline & $\leq 5$ Years & $0(0 \%)$ & $14(100 \%)$ & & & & \\
\hline \multirow[t]{3}{*}{5.} & \multicolumn{7}{|l|}{ Working Hour } \\
\hline & $>8$ hour/day & $2(22,2 \%)$ & $7(77,8 \%)$ & \multirow{2}{*}{0,681} & \multirow{2}{*}{0,667} & \multirow{2}{*}{0,170} & \multirow{2}{*}{2,607} \\
\hline & $\leq 8$ hour/day & $8(28,6 \%)$ & $15(71,4 \%)$ & & & & \\
\hline
\end{tabular}

The proportion of workers who have smoking habit on cadmium exposure in blood is $37.5 \%$ or 6 respondents while non-smokers are exposed to cadmium of $21.4 \%$ or 3 respondents. Chi Square statistical analysis results obtained p-value of $0.440(>\alpha=0.05)$ showed that there is no relationship between smoking habits against cadmium in the blood of metal foundry workers. The results of this study is similar to the research conducted by Ghazali and Luckett which showed no significant relationship between smoking habit and cadmium content $^{7.8}$

Psychology capacity like smoking habit, alcohol and suplement drink consumption greatly affected the performance and productivity of worker ${ }^{9}$ Smokers prone to have respiratory disorder compared to non smokers when they were in hazardous environment. There were 2000 chemicals in the cigarrette, and 1200 of them contain toxic substances for human health. Besides that, exposure to cigarette smoke have strong relations with the DNA damage induced by oxidative stress (oxidative stress) and carcinogenesis ${ }^{10}$. Some studies indicate that smoking can caused and increased of cancer in humans, such as lung cancer, mouth, pharynx, laring, esophagus, bladder, stomach, pancreas, kidney, uterus, cervix and myeloid leukemia" ${ }^{11}$.

Harmful substances in cigarettes in addition to triggering direct changes to the kidney organs, also brings the risk of increasing blood and heart pressure. Increased blood pressure is an important factor in the progression of $\mathrm{CKG}$ disease. The mechanism of last renal impairment may be seen histopathologically ${ }^{12}$, Smokers are generally exposed to cadmium through inhalation. In a cigarette there is $2 \mu \mathrm{g}$ of cadmium, where almost $2-10 \%$ of it turns into cigarette smoke ${ }^{13}$. Smokers generally have their blood contained with cadmium and the content in the body is twice higher than those who do not smoke ${ }^{14}$. In addition, smokers will also have a high cadmium content in their urine ${ }^{13}$.

Based on bivariate analysis, it is found that the proportion of exposed workers cadmium have normal nutritional status of $45 \%$ or 9 respondents. Chi Square statistical analysis result obtained P-Value of 0,013 (> $\alpha=0,05)$ with value of RP: 1,818 and CI $95 \% ; 1,223-$ 2,703 which means that people with normal nutritional status have a risk of exposure to cadmium in the blood of 1.818 times compared to people with abnormal nutritional status.

Human weight reflects the nutritional status of a person. Poor nutrition will affect the decrease of one's body endurance and it brings health problems. People with ideal body weight will have enough nutrients that block the presence of cadmium into the body in replacing nutrients (zinc, iron, copper, selenium, 
calcium, pyridoxine, ascorbic acid, and protein). Most cadmium toxicities occur due to the deficiency of the above-mentioned elements causing an increase in cadmium absorption ${ }^{15}$.

Factors of the body such as immunity, the power of respondents in exhaling, the ability of the cilia to filter out the fume dust produced during the casting process, and the pattern of consumption of eating and drinking, is a factor that affects the existence of high cadmium in the body and the existence of zinc ( $\mathrm{Zn}$ ) enzymes such as Gluthatione S-transferase ${ }^{16}$.

Entrepreneurs should think about the problems faced by their employees who work over the regulated work hours or carry out the work that is considered heavy, to always provid food security (usually in the form of nutritious food) and extra food (Extra Voeding). Restrictions on working time, the provision of assured regular meal every working day, is an employer's policy to maintain the desired work productivity of the company from its employees. ${ }^{17}$

Based on bivariate analysis, the proportion of workers who are exposed to cadmium working in the foundry section was $44.4 \%$ or 8 respondents. The result of Chi Square statistic analysis obtained the P-Value of $0,049(>\alpha=0,05)$ showed that there was correlation between work type to cadmium substance in blood of metal foundry workers, with $\mathrm{RP}$ value: 5,333 and $\mathrm{Cl}$ $95 \% ; 0.762$ - 37.348 which means that people who work in the foundry have a risk of exposure to cadmium in the blood of 5.333 times than people who work in finishing.

OSHA estimates that 300,000 workers exposed to cadmium in the United States are present in industrial sector workers comprising metal smelting, welding and packaging. This study aims to determine factors that are related to cadmium levels in the blood of metal foundry workers. ${ }^{4}$

Based on the bivariate analysis, it is found that the proportion of workers exposed to cadmium has a work period over 5 years of $56.3 \%$ or 9 respondents. Chi-Chi statistical analysis results obtained P-Value value 0.001 $(>\alpha=0.05)$ showed that there is a relationship between the length of work against cadmium in the blood of metal foundry workers, with the RP value of: 0.438 and CI $95 \% ; 0.251-0.763$ which means people who work over 5 years have a risk of exposure to cadmium in the blood of 0.438 times compared to people who work under 5 years.
Respondents whose suffered from work-related complaints may caused by work under long working hours and long periode time (more than 3 years) and lack of PPE usage ${ }^{18}$. From research on working adults in USA show that long working hours indirectly precipitate workplace accidents by inducing fatigue or stress in affected workers and overtime schedules had the greatest relative risk of occupational injury or illness, followed by schedules with extended $(>12)$ hours per day and extended $(>60)^{19}$.

Based on bivariate analysis, the proportion of workers exposed to cadmium has working hours over 8 hours / day as many as $22.2 \%$ or 2 respondents, while those who have less than 8 hours / day of working hours $33,3 \%$ or 7 respondents. Chi Square statistical analysis results obtained P-Value $0.681(>\alpha=0.05)$ showed that there is no relationship between working hours of cadmium in the blood of metal casting workers.

This research is similar to the research done by Bagun Sugiharto which explains that there is no relation between work and the number of working hours per week with cadmium level in exhaust welding worker ${ }^{3}$. This inertial study with the study of Ghazali showed no association between length of service and cadmium content, but there was a significant relationship between the working period and the concentration of lead and arsenic metal ${ }^{7}$.

Exposure to the toxic cadmium (Cd) has adverse health effects an occupational or high level environmental exposure ${ }^{20}$. Cadmium exposure is an important risk for renal disfunction, bone disease and cancer, cadmium is associated with cardiovascular disease too ${ }^{21}$. So all workers who in foundry must used to Personal Protective Equipment (PPE) to contral hazards at work place.

\section{CONCLUSIONS}

There is a relationship between nutritional status, duration of work, and type of work to cadmium levels in the blood of metal foundry workers. In order to reduce cadmium exposure in the workplace there is a need to be have adequat ventilation in the workplace and the use of personal protective equipment.

\section{ACKNOWLEDGEMENTS}

The author would like to thank to all of responden in foundry workers at sub-district Ceper, Klaten, Central Java to support of this research and BBTKLPP Yogyakarta for analyzing blood of Cadmium. 
Conflict of Interest: The author declare that there is no conflict of interest in this research.

Ethical Clearance: Ethical clearance to conduct this study was obtained from Health Research Ethics Committee, Faculty of Public Health Diponegoro University (No.026/EC/FKM/2018)

\section{REFERENCES}

1. Buranatrevedh S. Health Risk Assesment of workers exposed to metals from an aluminium production plant, J Med Assoc Thai; 2010.Dec :93 Suppl 7: S136-41

2. Agency for Toxic Subtances and Disease Registry (ATSDR). CERCLA priority list of hazardous suntances. Washington DC: Department of Health and Human Services, 2007

3. Morris TK.Cadmium exposures at three nonferrous foundries: an unexpected trace source. J Occup Environ Hyg 2004 Jan; 1(1):39-44

4. OSHA. Cadmium, Occupational Safety and Health Administration. USA. 2004

5. Akesson A. Lundh, Vahter M, et al .Tubular and glomerular kidney effects in swedish women with low environmental cadmium. Environ Health Perspect 2005; $113: 1627-31$

6. Hambach, R.D, Lison, P.C D'Haese,J Weyler,E De Graef, A De Schryver, LV Lamberts, M Van Sprundel. Co-exsposure to leads increases the renalresponsetolow levels of cadmium in metallurgyworkers. Toxicology Letters 222 . 2013: 233-238

7. Luckett BG, SuL J, Rood JC, Fontham ET. Cadmium exposure and pancreatic cancer in south Louisiana. Journal of environmental and public health. 2012;1-11

8. Ghazali AR, Razak A, Ezzazulianie N, Othman MS, thman H, Ishak I, Lubis SH, Mohammad N, Abd Hamid Z, Harun Z, Kamarulzaman F. Study of heavy metal levels among farmers of Muda Agricultural Development Authority, Malaysia. Journal of environmental and public health. 2012; 1-4

9. Setyaningsih, Y, Husodo A.H, Astuti I, Detection of Urinary 8-hydroxydeoxyguanosine(8-OHdG) levels as biomarker of oxidative DNA damage among home industry workers exposed to chromium. Procedia Environment Science. 2015 : Vol 23,pp 290-296

10. Patel B.P and U.M.Rawal, Tobacco, antioxidant enzymes, oxidative stress, and genstic susceptibility in oral cancer, Am. J. Clin. Oncol. 2018 : vol. 31, pp. 454-459

11. Lodovici, M and Bigagli, E. Biomarkers of induced active and passive smoking damage, Int J Env Res Public Health.2009: vol. 6, pp. 874-888

12. Orth HS. Smoking: a risk factor for progression of chronic kidney disease and for cardiovascular morbidity and mortality in renal patients--absence of evidence or evidence of absence? Clin J Am Soc Nephrol. 2008; Jan;3(1):226-36

13. Mannino DM, Holguin F, Greves HM, SavageBrown A, Stock AL, Jones RL. Urinary cadmium levels predict lower lung function in current and former smokers: data from the Third National Health and Nutrition Examination Survey. US National Library of MedicineNational Institutes of Health. Thorax 2004 Mar;59(3):194-8.

14. Walker, JR Orville . Marketing Strategy: A Decision-Focused Approach. Mc Graw-Hill, New York. 2003

15. Kobayashi E,Suwazuno Y, Dochi M, Honda R,Kido T, Nagakawa H. Influence of consumption of Cadmium-polluted rice from Jinzu River water on occurance of renal tubular dysfunct researchion and/or Itai-Itai disease. Biological Trace Element research. $200927: 257-268$

16. Mulder TP, Peters WH. Variability of glutathioneStransferase ain human liver and plasma.Clinical chemistry. $1999: 355-359$

17. Madeddu R, Solinas G, Forte G Bocca B, Assara $\mathrm{Y}$, Tolu $\mathrm{P}$, et al. Diet and nutrients are contributing factors that influence blood cadmium levels. Nut Res 2011; 31(9) :691-72011

18. Sagita Q M, Yuliani Setyaningsih, Sulistiyani , Determinant Factors of Work-Related Complaints, International Journal of Public Health Science (IJPHS) 2018 : Vol.7, No.1, , pp. 46-50

19. A. E. Dembe, et al., The impact of overtime and long work hours on occupational injuries and illnesses: new evidence from the United States,2005 Occup Environ Med, vol. 62, pp. 588-597

20. Norberg GF, NogawaK, Norberg M. Cadmium In : Handbook on the Toxicology of Metals (Nordber GF, Fowler GF, Nordberg $M$, eds) $\$$ th ed. Amsterdam, Netherlands .Elsiever 2015 :667-176

21. Hsu CW, Ja Liang Lin, Dan Tzu Lin Tan, Wen Huang Huang, Kuan Hsing Chen, Tzung Hai Yen, Association between blood cadmium levels and malnutrition in peritoneal dialysis BMC Neprology 2014, 15-17 


\section{Individual Characteristic and Cadmium Level in Blood on Tradisional Metal Foundry Workers}

ORIGINALITY REPORT

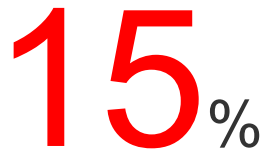

SIMILARITY INDEX

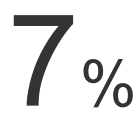

INTERNET SOURCES
$11 \%$

PUBLICATIONS
$3 \%$

STUDENT PAPERS

PRIMARY SOURCES

1

Yuliani Setyaningsih, Indwiani Astuti, Adi Heru

Husodo. "Determinants Levels of Urinary 8-

Hydroxydeoxyguanosine among Chromium

Electroplating Workers", International Journal of

Public Health Science (IJPHS), 2016

Publication

2 Qoni Mulia Sagita, Yuliani Setyaningsih,

Sulistiyani Sulistiyani. "Determinant Factors of

Work-Related Complaints", International Journal

of Public Health Science (IJPHS), 2018

Publication

3 journal.ugm.ac.id

Internet Source 



\section{Individual Characteristic and Cadmium Level in Blood on Tradisional Metal Foundry Workers}

GRADEMARK REPORT

FINAL GRADE

10

PAGE 1

PAGE 2

PAGE 3

PAGE 4

PAGE 5
GENERAL COMMENTS

Instructor 